\title{
Individual growth of Drepanotrema cimex (Pulmonata: Planorbidae) from Arenalcito pond, natural reserve multiple uses Martin García Island, Buenos Aires, Argentina
}

\author{
Martín-Stella, M. ${ }^{a, b,{ }^{*}}$, Díaz-Ana, $C{ }^{b, c}$ and Rumi, $A .^{b, d}$ \\ ${ }^{a}$ Investigador Comisión de Investigaciones Científicas de la provincia de Buenos Aires, Buenos Aires, Argentina \\ ${ }^{b}$ División Zoología Invertebrados, Facultad de Ciencias Naturales y Museo, Universidad Nacional de La Plata, \\ La Plata, 1900 Buenos Aires, Argentina \\ ${ }^{c}$ Becario Estimulo a las Vocaciones Científicas, Universidad Nacional de La Plata, Paseo del Bosque S/N, La Plata, 1900 \\ Buenos Aires, Argentina \\ ${ }^{d}$ Investigador Consejo Nacional de InvestigacionesCientificas y Técnicas, Argentina \\ *E-mail:smartin@fcnym.unlp.edu.ar
}

Received July 4, 2012 - Accepted November 5, 2012 - Distributed November 29, 2013

(With 7 figures)

\begin{abstract}
The species of the genus Drepanotrema, most of them endemic to the Neotropical region, belong to the Planorbidae. Of the nine species of this genus, six are found in Argentina. The present investigation analysed the individual growth of Drepanotrema cimex in Arenalcito pond ( $34^{\circ} 11^{\prime} \mathrm{S}, 58^{\circ} 15^{\prime} \mathrm{W}$ ), Martín García Island Natural Reserve of Multiple Uses, Buenos Aires Province, Argentina. A total of 14 samples were collected $(n=1931)$ from February 2006 to June 2007. Five environmental variables were measured: water temperature, dissolved oxygen $\left(\mathrm{mg} \mathrm{L}^{-1}\right)$, electrical conductivity $\left(\mu \mathrm{S} \mathrm{cm}^{-1}\right)$, total dissolved solids, and $\mathrm{pH}$. The individual growth of the species was analysed mathematically by means of the von Bertalanffy equation, where: $\mathrm{Lt}=5,6\left(1-\mathrm{e}^{-2,0592(\mathrm{t}-0,293)}\right)$. The parameter L $\infty$ was estimated by the Ford-Walford Method. The population of D. cimex was characterised by a complex and dynamic size structure throughout the annual cycle. The analysis of the curves revealed unimodal (2006) and polymodal (April to June 2007) distributions, which pattern served to identify the existence of cohorts within the population studied.
\end{abstract}

Keywords: Drepanotrema cimex, individual growth, Bertalanffy equation, Martín García Island.

\section{Crescimento individual de Drepanotrema cimex (Moricand, 1839) (Pulmonata, Planor- bidae) de Arenalcito, Reserva Natural de Usos Múltiples "Isla Martín García", Argentina}

\section{Resumo}

As espécies do gênero Drepanotrema, a maioria delas endêmicas da região Neotropical, pertencem ao Planorbidae. Das nove espécies desta família, seis são encontradas na Argentina. Este artigo analisa o crescimento individual de Drepanotrema cimex na lagoa de Arenalcito, Reserva Natural de Usos Múltiples Ilha Martín García, Buenos Aires, Argentina $\left(34^{\circ} 11^{\prime} \mathrm{S}-58^{\circ} 15^{\prime} \mathrm{W}\right)$. A amostragem foi realizada entre fevereiro de 2006 e junho de 2007 . Durante o curso das campanhas foram obtidas 14 amostras $(n=1931)$. Cinco variáveis ambientais foram medidas: temperatura da água, oxigênio dissolvido $\left(\mathrm{mg} \mathrm{L}^{-1}\right)$, condutividade elétrica $\left(\mathrm{uS} \mathrm{cm}^{-1}\right)$, sólidos dissolvidos e $\mathrm{pH}$. $\mathrm{O}$ crescimento individual das espécies foi analisada matematicamente por meio da equação de von Bertalanffy em que: $\mathrm{Lt}=5,6\left(1-\mathrm{e}^{-2,0592(\mathrm{t}-0,293)}\right)$. O paràmetro L $\infty$ foi estimada pe lo método de Ford-Walford. A população de D.cimex foi caracterizada por uma estrutura complexa e dinâmica de tamanho ao longo do ciclo anual. A análise das curvas mostrou distribuições unimodais (2006) e polimodais (abril-junho 2007), identificando a existência de coortes na população estudada.

Palavras-chave: Drepanotrema cimex, crescimento individual, equação Bertalanffy, Ilha Martín García.

\section{Introduction}

Most of the species of Drepanotrema (Crosse and Fischer, 1880), belonging to the family Planorbidae, are endemic to the Neotropical region. This genus includes nine species, of which six are found in Argentina: Drepanotrema cimex (Moricand, 1839), Drepanotrema anatinum (d'Orbigny,1835), Drepanotrema depressissimum (Moricand, 1839), Drepanotrema heloicum (d'Orbigny, 1835), Drepanotrema kermatoides (d'Orbigny, 1835), and Drepanotrema lucidum (Pfeiffer, 1839) (Paraense, 2005; Rumi et al., 2006). To date, the ecological and biological aspects of Drepanotrema are poorly 
known (Bonetto et al., 1990; Rumi, 1991; Hamman et al., 1993; Rumi et al., 1997 and 2004; Bueno-Silva and Fischer, 2005); the morphology and taxonomy has been studied by Baker (1945), Paraense and Deslandes (1958), and Paraense (1975 and 1980). Also, the life cycle of natural systems in Argentina has been little studied, except for some isolated observations (Rumi et al., 2004 and 2007).

The aim of the present study was to analyse the individual growth of $D$. cimex in Arenalcito Pond in the Martín García Island Natural Reserve of Multiple Uses. To date, several investigations have been carried out on the ecology and biodiversity of the Reserve's fauna and flora (Lahitte and Hurrell, 1996 and 1997; Rumi et al., 1996; Martín and Negrete, 2006; Martín 2008; César et al., 2008; Martín et al., 2009; Martín and Díaz, 2012).

\section{Materials and Methods}

Martín García Island is located in the upper Río de la Plata estuary, to the south of the mouth of the Uruguay River ( $34^{\circ} 11^{\prime} 25^{\prime \prime} \mathrm{S}$ and $58^{\circ} 15^{\prime} 38^{\prime \prime} \mathrm{W}$ ) (Figure 1). The island constitutes an outcropping of the Brazilian massif of Precambrian crystalline basement rocks, overlaid by sediments from the Holocene and Pleistocene (Quaternary). In the central-eastern sector of the island, there is a plateau-like area gradually sloping downwards towards the sea and more abruptly towards the north of the island, where the terrain continues as a plain that ends in the river (Ravizza, 1984). The study site was Arenalcito pond located near Day Península (on the eastern sector of the island). This pond is an inland eutrophic body of water fed exclusively by rainfall and thus undergoing occasional desiccation periods. The vegetation present consists in aquatic free-floating herbs, belonging to the Hydrocaritaceae family (Lahitte and Hurrell, 1996).

A total of 14 samples were collected from February 2006 to June 2007 and five environmental variables mea-

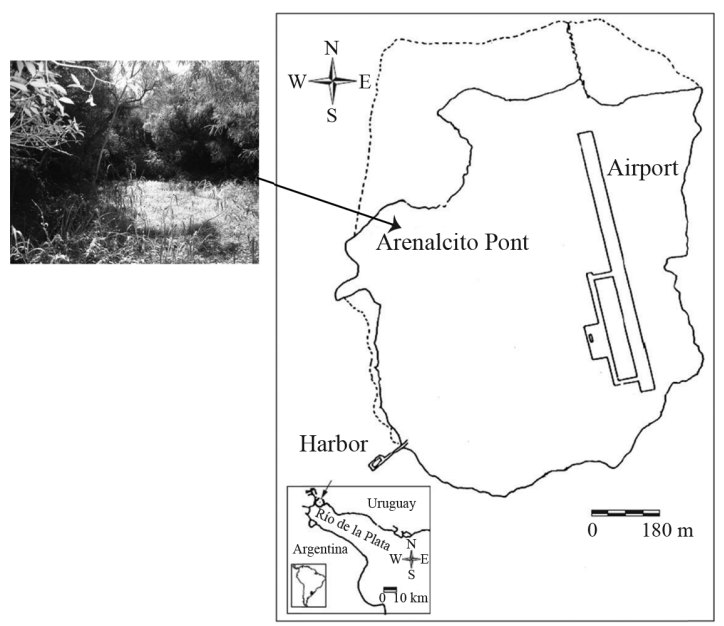

Figure 1 - Martín Garcia Island map with station Arenalcito pond. sured with a digital Water Quality Meter (Sper Scientific $\mathrm{Ltd})$ : water temperature, dissolved oxygen $\left(\mathrm{mg} \mathrm{L}^{-1}\right)$, electrical conductivity $\left(\mu \mathrm{S} \mathrm{cm}^{-1}\right)$, total dissolved solids (TDS), and $\mathrm{pH}$.

Snails were collected with sieves of $20 \mathrm{~cm}$ diameter and $0.15 \mathrm{~cm}$ mesh size and then fixed with Henry-Raillet and Carnoy solution. Snail relative abundance was calculated as captures per unit effort as specimens (CPUE), that is, specimens/ $60 \mathrm{~min} /$ person. The snails were identified under a stereoscopic microscope according to the morphological guidelines of Paraense (1975). The maximum shell diameter of each specimen was measured with a caliper to a precision of $0.01 \mathrm{~mm}$. The shell length was selected as the parameter for determining the monthlysize frequency histograms and identifying the modal lengths $(\mathrm{Lm})$ for subsequent graphical representation of these parameters as a function of time. Individual growth was analysed by means of the von Bertalanffy growth equation (Bertalanffy, 1960): $\mathrm{Lt}=\mathrm{Lmax}(1-\mathrm{e}-\mathrm{k}(\mathrm{t}-\mathrm{to})$ ), where: $\mathrm{Lt}=$ the length at a specific time $\mathrm{t}$; $\mathrm{Lmax}=$ the asymptotic maximum body length; to= the hypothetical time in which the length of the individuals is "zero"; $\mathrm{t}=$ time; $\mathrm{k}=$ the growth rate.

To make the intervals on the time axis among the samples proportional to the time spent in each sampling period, the sampling dates were transformed into parts of the year (between 0 and 1), according to the following expression: Parts of the year $=[(m-1) * 30+d] / 365$, where $\mathrm{m}=$ number of the month considered, and $\mathrm{d}=$ number of days spent in the month cited. The parameter L $\infty$ (maximum body length that an individual of a cohort can reach) was calculated by the Ford-Walford method, where estimations of $\mathrm{Lt}+1$ were graphically represented as a function of $\mathrm{L}$ for each time $\mathrm{t}$. The parameters $\mathrm{k}$ and towere determined by linear regression between $\ln [(1-$ $\left.\mathrm{Lt}) \mathrm{Lmax}^{-1}\right]$, the dependent variable, and $\mathrm{t}$, the independent variable; where $\mathrm{kTo}=$ the ordinate value at the origin and becomes the (a) parameter of the Ford-Walford Method with $-\mathrm{k}$, the slope, becoming the (b) parameter and Lt being the length at time t. Finally, the curve obtained was compared with the one plotted from the von Bertalanffy model through the use of the $\mathrm{X}^{2}$ test for goodness of fit.

\section{Results}

The population of $D$. cimex was characterised by a complex and dynamic size structure throughout the annual cycle (Figure 2). The analyses of the curves revealed both unimodal (2006) and polymodal (April to June 2007) distributions, allowing the detection of cohorts within the population studied.

The cohort detected in 2006 was used to analyse the individual growth. The breeding period of this cohort took place during the summer and continued to develop until late summer 2007. During the sampling periods conducted in 2007 juveniles ( 2.5 to $3.1 \mathrm{~mm}$ ), adults ( 3.2 to $5.8 \mathrm{~mm}$ ) and seniles (5.9 to $7 \mathrm{~mm}$ ) were observed 
Individual growth of Drepanotrema cimex (Pulmonata: Planorbidae) from Arenalcito pond
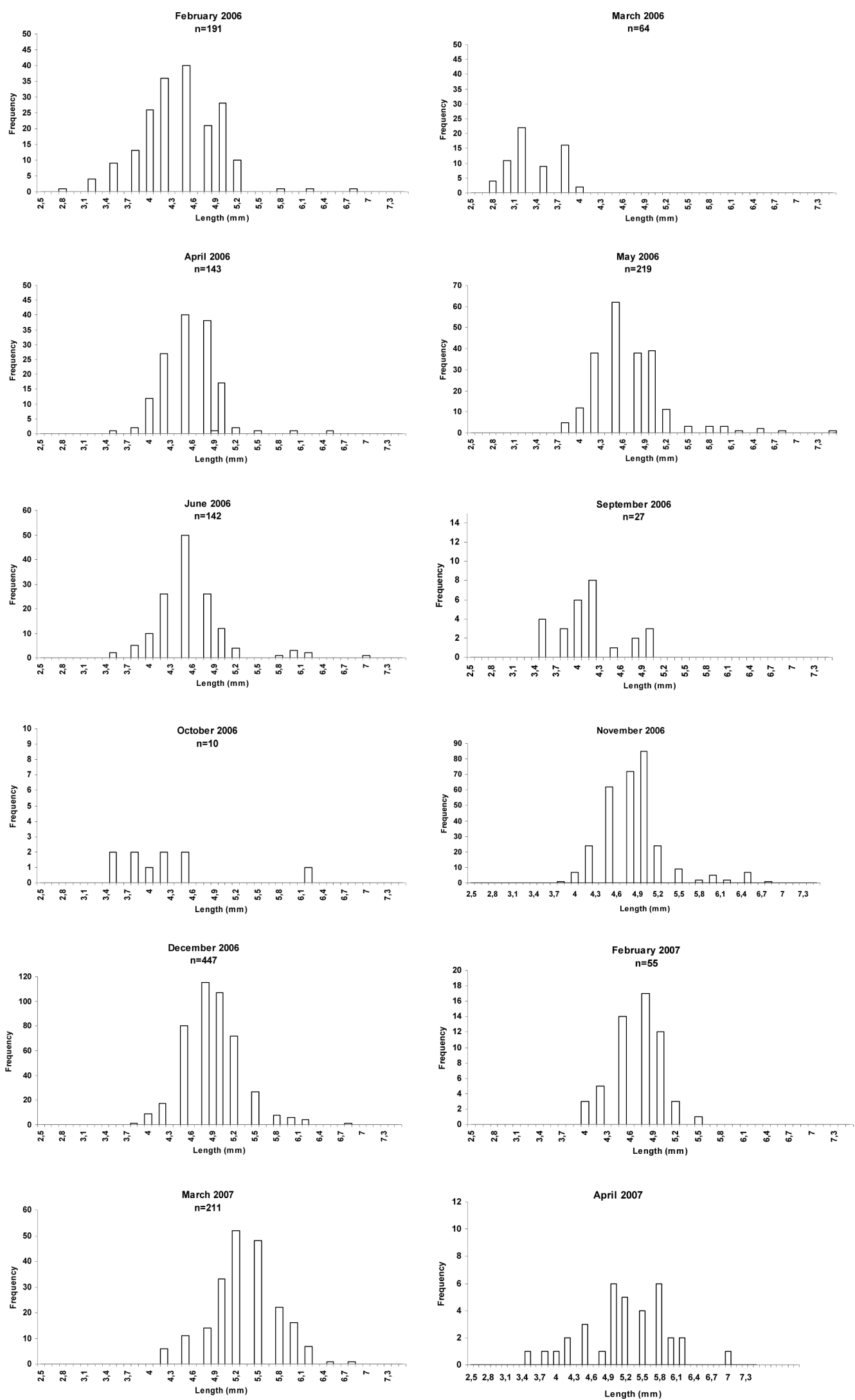

Figure 2 - Size-frequency distributions of Drepanotrema cimex in Arenalcito pond on Martín García Island. 

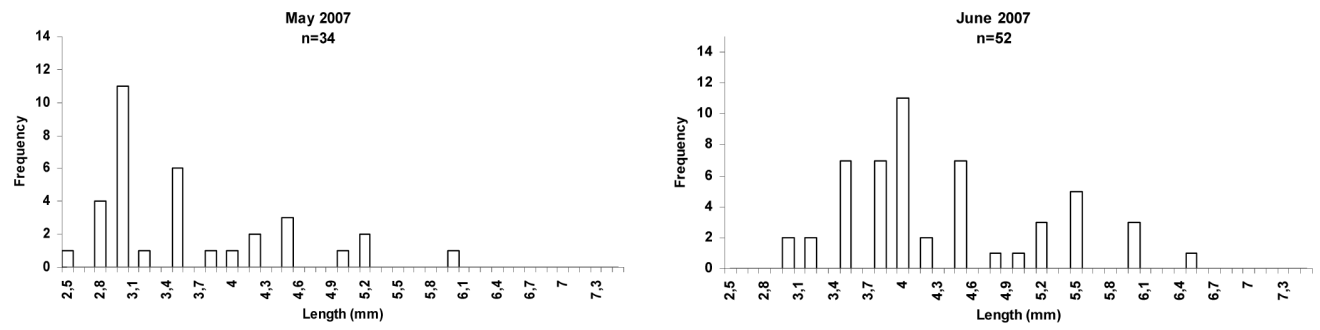

Figure 2 - (cont.)

within the population, thus indicating an average longevity of a year to a year and a half (Figure 3 ).

The maximum length reached by individuals according to the Ford-Walford Method was $5.6 \mathrm{~mm}$ (Figure 4), the growth rate $\mathrm{k}=2.0592$ and to $=0.293$, the time during

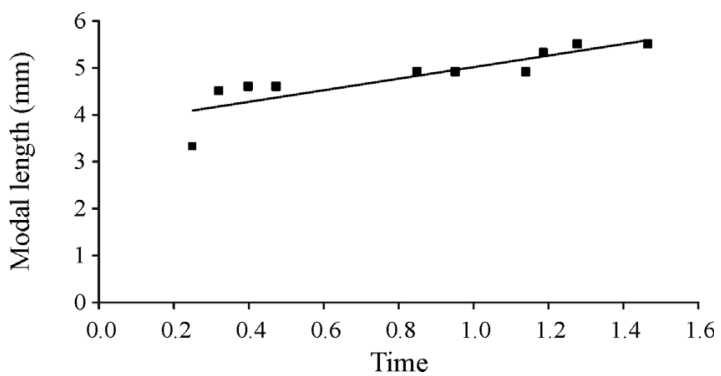

Figure 3 - Modal length (mm) of Drepanotrema cimex between 2006 and 2007, with the time being expressed in parts of the year.

Method Walford

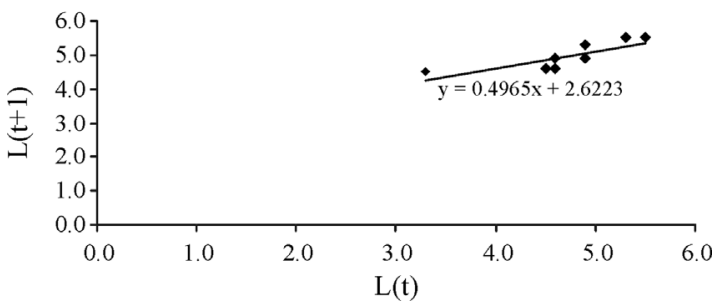

Figure 4 - Ford Walford Method for estimating the parameter $\mathrm{L} \infty$.

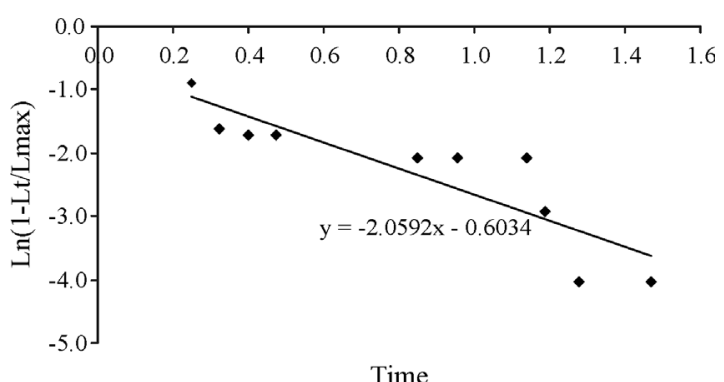

Figure 5 - Regression curves to obtain the constants $\mathrm{k}$ and to. which they are "zero-length" or in the breeding period (Figure 5). The curve obtained did not show significant statistical differences according to the von Bertalanffy model $\left(X^{2}=0.639, d f=9, p>0.05\right)$ (Figure 6), indicating that this model is a useful tool to predict the growth of populations belonging to this species (Rumi, 2007). The relationship between population structure and size revealed the presence of dominant classes, corresponding to (4 to $5.2 \mathrm{~mm}$ ) at the beginning of the reproductive period in February and March 2006 and from November 2006 to March 2007.

In February and March 2006 and from November 2006 to March 2007 the highest values of water temperature were recorded $\left(23\right.$ to $\left.27.5^{\circ} \mathrm{C}\right)$. The percentage of dissolved oxygen was low throughout the year; while the $\mathrm{pH}$ was stable and alkaline during the sampling period, ranging between 5.5 and 6.58. The electrical conductivity was low ( 6 to $62 \mu \mathrm{S} \mathrm{cm}^{2}$ ) attributable to a poor contribution to the pond from rainfall. Of all the environmental parameters, the water temperature was the most preponderant condition affecting population growth (Figure 7).

\section{Discussion}

The population of $D$. cimex showed unimodal and a polymodal distribution, this finding enabled a differentiation among the cohorts that indicated no coexistence of different generations throughout the annual cycle. The peak of abundance of the $D$. cimex population in that period agrees with the data recorded by Michelson and Mota (1982) and Pointier and David (2004); indicating that species of Planorbidae such as $D$. depressissimum, D. lucidum, and some species of Biomphalaria, are fa-

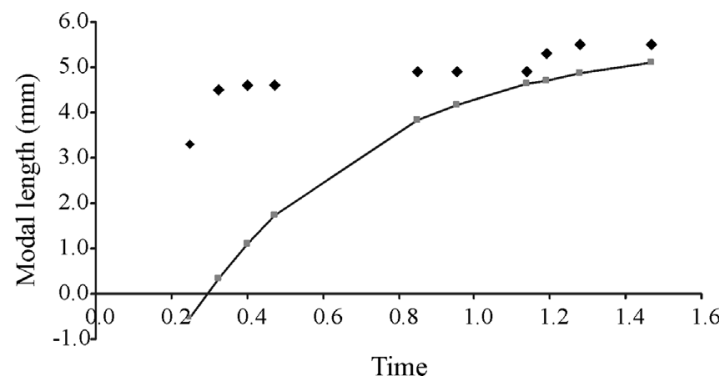

Figure 6 - Growth curves of Drepanotrema cimex in Arenalcito pond on Martín García Island. 


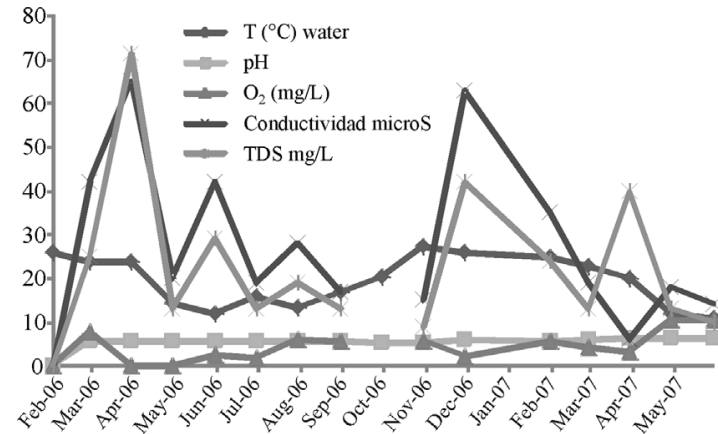

Figure 7 - Annual distribution of water temperature, dissolved oxygen, $\mathrm{pH}$ and conductivity in Arenalcito pond, Martín García Island.

vored by rainy seasons. These results agreed with those of Bueno-Silva and Fischer (2005) for D. cimex in the Barigüí Park, Curitiba (Brazil). In the Cantera Grande Lake, located at the southern end of the Martín García Island, this species was also abundant during the summer and fall of 1995 (Rumi et al., 2004).

Ituarte (1989) observed the unimodal characteristic of the growth curves of populations of Biomphalaria straminea (Dunker, 1848). We conclude that unimodality and only a single reproductive period of a given species are distinctive characteristics of the ecology of the Planorbidae family. Rumi et al. (2007) observed that the growth rate of $D$. kermatoides in the Paiva Pond of Corrientes, Argentina was much higher than that observed for $D$. cimex in the Arenalcito pond mainly because the temperatures recorded on the Island are lower than those registered in Corrientes.

Among the most significant environmental parameters affecting growth of populations of $D$. cimex, water temperature is the most influential. According to Rumi (1991), this characteristic is a limiting condition for the development of the populations of all the species belonging to the Planorbidae family.

\section{Acknowledgments}

Financial support for this work was provided by an institutional grant from the Comisión de Investigaciones Científicas de la Provincia de Buenos Aires (CIC), PICT (2042-2008) and Facultad Ciencias Naturales y Museo, La Plata (UNLP) (Proyect 11/N470). The authors wish to thank the staff members of the Prefecture Naval Argentina Isla Martín García, Mr. José Maciel and are grateful to Dr. Donald F. Haggerty, a retired career investigator and native English speaker, for editing the final version of the manuscript.

\section{References}

BAKER, FV., 1945. The Molluscan Family Planorbidae. Illinois: Urbana, University of Illinois Press. 530 p.

BONETTO, AA., RUMI, A. and TASSARA, MP., 1990. Notas sobre el conocimiento limnológico de los gasterópodos paranaenses y sus relaciones tróficas. II. Planorbidae, con aspectos distribucionales y sanitarios. Ecosur, vol. 16, p. $69-84$.

BUENO-SILVA, M. and FISCHER, ML., 2005. Dinâmica populacional de Drepanotrema cimex (Moricand, 1839) (Mollusca: Basommatophora: Planorbidae) no Parque Barigüi, Curitiba, Paraná, Brasil. Biotemas, vol. 18, no. 2, p. 129-141.

CÉSAR, II., MARTÍN, SM., RUMI, A. and TASSARA, MP., 2008. Moluscos (Gastropoda y Bivalvia) de la Reserva de Usos Múltiples Isla Martín García, Río de la Plata: Biodiversidad y Ecología. In Proceedings IV Congreso Argentino de Limnología. San Carlos de Bariloche. p. 89.

ITUARTE, CF., 1989. Growth dynamics in a natural population of Biomphalaria straminea (Dunker, 1848) from Bella Unión, Artigas, Uruguay. Studies on Neotropical Fauna and Environment, vol. 24, no.1, p. 35-40.

LAHITTE, HB. and HURRELL, JA., 1996. Plantas hidrófilas de la Isla Martín García (Buenos Aires, Argentina). Buenos Aires: CIC. 235 p. Serie Informe 52.

LAHITTE, HB., HURRELL, JA., BELGRANO, MJ., JANKOWSKI, LS., MEHLTRETER, K., HALOUA, MP., CANDA, G., 1997. Plantas de la Costa: Las plantas nativas y naturalizadas más comunes de las costas de Delta del Paraná, Isla Martín García y Rivera Platense. Buenos Aires: LOLA. 200 p.

MARTÍN, SM. and NEGRETE, LHL., 2006. Primer registro de Heleobia guaranitica (Doering, 1884) (Gastropoda: Cochliopidae) en la Reserva Natural de Usos Múltiples Isla Martín García. Comunicaciones Sociedad Malacología Uruguay, vol. 9, no. 89, p. 71-73.

MARTÍN, SM., 2008. Individual growth Heleobia piscium in natural populations (Gastropoda: Cochliopidae) from the Multiple Use Natural Reserve Isla Martín García, Buenos Aires, Argentina. Brazilian Journal of Biology, vol. 68, no. 3, p. 617-621.

MARTÍN, SM., CÉSAR, II. and LIBERTO, R., 2009. Distribution of Deroceras reticulatum (Müller, 1774) (Pulmonata Stylommatophora) in Argentina with first record of the Reserva de Usos Múltiples Isla Martín García, Río de la Plata superior. Brazilian Journal of Biology, vol. 69, no. 4, p. $1115-1119$.

MARTÍN, SM. and DÍAZ, AC., 2012. Population structure of Uncancylus concentricus (d'Orbigny, 1835) (Ancylidae, Pulmonata, Basommatophora) in the Multiple Use Reserve Martín García Island, Upper Río de la Plata, Argentina. Brazilian Journal of Biology, vol. 72, no. 1, p. 65-70.

PARAENSE, WL. and DESLANDES, N., 1958. The Brazilian species of "Drepanotrema". IV. "D. cimex" (Moricand, 1837). Revista Brasileira de Biologia, vol. 18, p. 187-192.

PARAENSE, WL., 1975. Estado atual da sistemática dos planorbídeos brasileiros (Mollusca, Gastropoda). Arquivos do Museu Nacional, vol. 55, p.105-128.

PARAENSE, WL., 1980. Drepanotrema cimex: synonymy, variation and geographical distribution (Mollusca, Planorbidae). Revista Brasileira de Biologia, vol. 40, p. 101113.

PARAENSE, WL., 2005. Planorbidae, Lymnaeidae and Physisdae of Argentina (Mollusca: Basommatophora). Memórias do Instituto Oswaldo Cruz, vol. 100, no. 5, p.491-493.

RAVIZZA, GB., 1984. Principales aspectos geológicos del Cuaternario en la Isla Martín García, Río de la Plata superior. Revista Asociación Geológica Argentina, vol. 39, no. 1-2, p. 125-130.

RUMI, A., 1991. La Familia Planorbidae Rafinisque, 1815 en la República Argentina. In CASTELLANOS, Z. (Ed.). Fau- 
na de Agua Dulce de la República Argentina. Buenos Aires: PROFADU (CONICET). p. 1-51.

RUMI, A., MARTÍN, SM., TASSARA, MP. and DARRIGRAN, GA., 1996. Moluscos de agua dulce de la Reserva Natural e Histórica Isla Martín García, Río de la Plata, Argentina. Comunicaciones de la Sociedad Malacológica del Uruguay, vol. 8, no. 70-71, p. 7-12.

RUMI, A., GUTIERREZ GREGORIC, DE., ROCHE, MA. and TASSARA, MP., 2004. Population structure in Drepano- trema kermatoides and D. cimex (Gastropoda, Planorbidae) in natural conditions. Malacología, vol. 45, p. 453-458.

RUMI, A., GUTIERREZ GREGORIC, DE. and ROCHE, MA., 2007. Growth rate fitting using the von Bertalanffy model: analysis of natural populations of Drepanotrema spp. snails (Gastropoda: Planorbidae). Revista Biologia Tropical, vol. 55, p. 559-567. 